\title{
College Libraries:
}

\section{A Comparative Analysis}

\section{in Terms of the ACRL Standards}

\begin{abstract}
A quantitative analysis of 1977 HEGIS data bearing on college libraries in terms of the ACRL Standards for College Libraries (1975) concludes that most of the libraries do not meet the Standards' criteria for collection size and development, staff, and budget. Variables in the Standards not included in the HEGIS data are not analyzed here. More detailed surveys of library characteristics and fuller financial support for library operations are needed to enhance both this kind of analysis and libraries and their standards in the future.
\end{abstract}

\section{INTRODUCTION}

The 1975 Standards for College Libraries $^{1}$ by the Association of College and Research Libraries (ACRL, American Library Association) is the focal point for this study. It is a systematic and quantitative assessment of college libraries in terms of the Standards. The data for the study are derived from national survey information collected by the National Center for Educational Statistics (NCES), U.S. Office of Education, Fall 1977. The four Higher Education General Information (HEGIS) surveys of academic libraries, faculty, enrollment, and finance were produced in machine-readable form by NCES; they comprise the most recent information available at this time. Financial support for computing services to generate the statistics for this report was provided primarily by ACRL. Additional aid was provided by the Computation Center, the School of Library Science, and the Institute for Research in Social Science-all of the University of North

Ray L. Carpenter is associate professor, School of Library Science, The University of North Carolina at Chapel Hill.
Carolina at Chapel Hill. Members of the ACRL Committee on College Library Standards Revision-Pat Sacks, Jasper Schad, and Arthur Monke, chair-made valuable contributions to the design of this study.

The libraries to which the standards apply are those classified by the Carnegie Commission on Higher Education as Liberal Arts Colleges I and II and Comprehensive Universities and Colleges I and II. ${ }^{2}$ The usable data gathered by NCES included responses from 95 percent of the relevant institutions. While the aggregate of institutions fits the Carnegie Commission's and the ACRL Standards' intended audience, the classification of types of institutions in this study does not correspond precisely with those of the Carnegie Commission. In this study, tables present summary information for all institutions (libraries) and, with few exceptions, for those schools classed as private graduate, private undergraduate, public graduate, and public undergraduate. The number of each of these types appears in each table. In most of the crosstabulations the four types of institutions constitute, respectively, 23 percent, 45 percent, 25 percent, and 7 percent of the total number of libraries analyzed $(1,146)$. 
All private and public institutions have programs for the baccalaureate degree: the undergraduate institutions, comprising 52 percent of the total, prepare only for the baccalaureate and one or a very few first professional degrees, typically a M.Ed. Graduate institutions are defined as those that grant master's degrees, have programs beyond the master's not leading to the doctorate, and some doctorate degrees (fewer than ten per year). Thus, large doctorategranting or research universities, two-year institutions, and a large number of specialized institutions such as theological seminaries are not included in this study. The standards are not intended to apply to them.

The four major topical categories in this analysis deal with collections, staff, budget, and service. Only the statistics available from NCES were analyzed, and as NCES did not collect data about characteristics of building space in 1977, no report related to this major standard is included here. More important, many of the major factors in the Standards, for example those which deal with administration policy, are qualitative. There are no data about these qualitative factors, and no attempt is made here to examine libraries directly in these terms. Often, of course, the statistical information does lend a perspective or insight about some of these qualitative standards.

In the tables of this report the numbers in parentheses identify the number of libraries. Percentages do not always sum up to 100 percent due to rounding. Further, the summarizing measures of many variables have been rounded to the nearest 10 or 100 in order to avoid spurious precision and enhance readability. In nearly all of the tabulations, skewed distributions are common; they are frequently indicated by the contrasts between the means and medians. Consequently, the median more often represents a more valid average than does the mean.

In sum, the study is intended to tell us how well the more than 1,100 college and university libraries meet the ACRL standards, given the limitations of missing variables, the ever-present possibility of errors due to reporting, and the original data processing. All the probable sources of error typical of secondary analysis were eliminated by systematic screening of the data, school by school and variable by variable, by the author and other members of the ACRL Committee on Revision of College Library Standards. Careful use of this study can assist in the improvement of the understanding of the Standards and possibly their revision. Moreover, it is possible that by seeing the kinds and extent of libraries' shortcomings, tactics for improvement may be determined.

In comparing the characteristics of these libraries with the statements in the Standards, recall that the Standards are for adequate, not ideal, programs. The relevant statement from the Standards document is as follows:

The Standards ... do not present [an] unattainable ideal. They rather describe a realistic set of conditions which, if fulfilled, will provide an adequate library program in a college. ${ }^{3}$

\section{Collections}

The Basic Collection, defined in Formula A of the Standards, should consist of 85,000 volumes of books, plus fifteen volumes for each FTE student, 100 volumes for each faculty member, and various allowances for each field of study. The HEGIS data bases provide no information about the number of fields of study, majors or minors, but the basic collection size and holdings per student and faculty are known as shown in several tables below. Presumably in order to meet the standards of Formula A, no library can operate "adequately" with fewer than 100,000 volumes: hence the lowest row class for table 1 .

To illustrate more fully the implications for Formula A on collection size, consider the following hypothetical "model":

Basic collection

Assume 100 faculty

@100 volumes

Assume 1,500 students (a) 15 volumes

Assume 16 undergraduate major or minor fields @ 350 volumes

Assume no other special or graduate fields Total 
TABLE 1

Book Collection Size

\begin{tabular}{|c|c|c|c|c|c|}
\hline $\begin{array}{l}\text { No, of } \\
\text { Volumes }\end{array}$ & $\begin{array}{c}\text { TOTAL } \\
(\mathrm{N}=1134)\end{array}$ & $\begin{array}{c}\text { Private } \\
\text { Grad. } \\
(\mathrm{N}=261)\end{array}$ & $\begin{array}{c}\text { Private } \\
\text { Undgrad. } \\
\text { (511) }\end{array}$ & $\begin{array}{l}\text { Public } \\
\text { Grad. } \\
(287)\end{array}$ & $\begin{array}{c}\text { Public } \\
\text { Undgrad. } \\
(75)\end{array}$ \\
\hline$<100,000$ & $43 \%$ & $33 \%$ & $68 \%$ & $7 \%$ & $52 \%$ \\
\hline$<200,000$ & 34 & 43 & 26 & 38 & 40 \\
\hline$<300,000$ & 13 & 16 & 4 & 26 & 7 \\
\hline 300,000 or more & 10 & 9 & 2 & 29 & 1 \\
\hline Median Vols. & 112,800 & 133,700 & 79,800 & 224,700 & 97,700 \\
\hline Mean Vols. & 151,700 & 162,000 & 94,600 & 254,900 & 108,600 \\
\hline
\end{tabular}

Conclusions: (1) The majority of all undergraduate institutions, comprising 52 percent of these colleges and universities, have fewer than 100,000 volumes of books. Indeed, 55 percent of the private undergraduate institutions have fewer than 85,000 volumes, the standard for the Basic Collection in Formula A.

2. Given the hypothetical model above, the mean and median collection sizes of both public and private undergraduate institutions fall below the hypothetical 123,100 volume "requirement."

Another perspective of libraries and the formula for book-collection size appears when book stock is analyzed in terms of student enrollment (FTE students). Roughly speaking, the larger the student body the fewer the volumes per capita. More precise comprehension of table 2 may be facilitated by the following: Among all $(1,134)$ schools,

30 percent have fewer than 1,000 FTE students

27 percent have 1,000-1,999 FTE students

23 percent have 2,000-4,999 FTE students

20 percent have 5,000 or more FTE students.

Book holdings in volumes per faculty member are shown in table 3 . Inasmuch as
TABLE 3

BOOK HOLdings: Volumes PER FaCULTY

\begin{tabular}{lc}
\hline \hline Vols./Faculty & All Libraries \\
\hline$<1,000$ & $27 \%$ \\
$<2,000$ & 50 \\
$<3,000$ & 17 \\
3,000 or more & 5 \\
\hline
\end{tabular}

Median number of volumes per faculty $=1,410$

Mean number of volumes per faculty $=1,670$

most of the libraries in this study have fewer than 2,000 students, small faculties are to be expected. Among all schools,

28 percent have fewer than 50 full-time faculty

32 percent have $50-99$ full-time faculty 22 percent have 100-199 full-time faculty

18 percent have 200 or more full-time faculty.

The variations by type of institution are particularly great in comparing the private undergraduate institutions with others. The Standards state that "... it is good practice for a library to own any title that is needed more than six times a year." 4

The number of periodical subscriptions by type and size of college is shown in table 4. There are no available data to assess either the frequency of need for periodicals or the extent by which the periodical titles in

TABLE 2

BOOK Holdings: Volumes PER STUdent

\begin{tabular}{lcccc}
\hline \hline Vols./Student & FTE $<1,000$ & FTE $<2,000$ & FTE $<5,000$ & FTE 5,000 or more \\
\hline$<50$ vols. & $5 \%$ & $16 \%$ & $57 \%$ & $91 \%$ \\
$50<150$ & 72 & 75 & 40 & 9 \\
150 or more & 23 & 9 & 3 & 0 \\
\hline
\end{tabular}

All libraries Median number of volumes per FTE student $=63$

$(\mathrm{N}=1134)$ Mean number of volumes per FTE student $=85$ 
TABLE 4

Number of Periodical Subscriptions

\begin{tabular}{|c|c|c|c|c|c|}
\hline $\begin{array}{l}\text { No. Periodical } \\
\text { Subscriptions }\end{array}$ & $\begin{array}{l}\text { TOTAL } \\
(1,133)\end{array}$ & $\begin{array}{c}\text { Private } \\
\text { Grad. } \\
(261)\end{array}$ & $\begin{array}{c}\text { Private } \\
\text { Undgrad. } \\
(510)\end{array}$ & $\begin{array}{l}\text { Public } \\
\text { Grad. } \\
(287)\end{array}$ & $\begin{array}{c}\text { Public } \\
\text { Undgrad. } \\
(75)\end{array}$ \\
\hline$<500$ & $28 \%$ & $17 \%$ & $49 \%$ & $2 \%$ & $13 \%$ \\
\hline$<750$ & 22 & 25 & 29 & 4 & 31 \\
\hline$<1,500$ & 27 & 39 & 18 & 28 & 47 \\
\hline 1,500 or more & 23 & 19 & 4 & 66 & 9 \\
\hline Median No. & 755 & 848 & 510 & 1,970 & 802 \\
\hline Mean No. & 1,170 & 1,060 & 590 & 2,350 & 940 \\
\hline
\end{tabular}

these libraries are included in the "several good handlists ... of periodicals appropriate for college collections" as generally cited in the Standards document. ${ }^{5}$

Measures of book collection development appear in tables 5 and 6 . Nearly half of the modal type of libraries, those serving private undergraduate schools, acquired fewer than 3,000 volumes in 1977. By contrast, 58 percent of the public graduate schools' libraries acquired between 10,000 and 25,000 volumes. If we consider the number of titles published in the U.S. in 1977, the distribution in table 5 is afforded another in- terpretation. Excluding all new editions, books classed as juvenile, fiction, and medicine, the total U.S. titles for 1977 was approximately $26,000.6$ The median number of acquisitions, 4,770 volumes, presumably includes some retrospective materials, some multiple copies, and some works of foreign origin, allowing for a possible 10-15 percent selection of the titles appearing new that year.

An exact measure of library book acquisitions in terms of the Standards appears in table 6. The public-controlled institutions, on average, meet or exceed the standard.

TABLE 5

BOOK VOLUMES AdDEd PER YEAR

\begin{tabular}{|c|c|c|c|c|c|}
\hline Vols. Added & $\begin{array}{c}\text { Total } \\
(1,134)\end{array}$ & $\begin{array}{c}\text { Private } \\
\text { Grad. } \\
\text { (261) }\end{array}$ & $\begin{array}{c}\text { Private } \\
\text { Undgrad. } \\
\text { (511) }\end{array}$ & $\begin{array}{l}\text { Public } \\
\text { Grad. } \\
\text { (287) }\end{array}$ & $\begin{array}{c}\text { Public } \\
\text { Undgrad. } \\
(75)\end{array}$ \\
\hline$<3,000$ & $29 \%$ & $22 \%$ & $49 \%$ & $4 \%$ & $19 \%$ \\
\hline$<5,000$ & 23 & 27 & 31 & 5 & 24 \\
\hline$<10,000$ & 24 & 34 & 15 & 26 & 40 \\
\hline$<25,000$ & 21 & 15 & 6 & 53 & 17 \\
\hline 25,000 or more & 3 & 2 & 0 & 12 & 0 \\
\hline Median No. & 4,770 & 5,190 & 3,050 & 12,230 & 5,650 \\
\hline Mean No. & 7,490 & 6,890 & 3,850 & 14,780 & 6,530 \\
\hline
\end{tabular}

TABLE 6

Percent of BoOKSTOCK AdDed

(Standard: 5\% of the Collection Should Be Augmented Yearly)

\begin{tabular}{|c|c|c|c|c|c|}
\hline$\%$ Added & $\begin{array}{c}\text { Total } \\
(1,134)\end{array}$ & $\begin{array}{c}\text { Private } \\
\text { Grad. } \\
(261)\end{array}$ & $\begin{array}{c}\text { Private } \\
\text { Undgrad. } \\
(511)\end{array}$ & $\begin{array}{l}\text { Public } \\
\text { Grad. } \\
(287)\end{array}$ & $\begin{array}{c}\text { Public } \\
\text { Undgrad. } \\
(75)\end{array}$ \\
\hline$<3$ & $22 \%$ & $27 \%$ & $30 \%$ & $8 \%$ & $12 \%$ \\
\hline$<4$ & 22 & 28 & 27 & 12 & 13 \\
\hline$<5$ & 19 & 22 & 18 & 17 & 17 \\
\hline $\begin{array}{l}\text { Cumulative \% } \\
\text { Under } 5 \%\end{array}$ & $(63 \%)$ & $(77 \%)$ & $(75 \%)$ & $(37 \%)$ & $(42 \%)$ \\
\hline$<6$ & 13 & 13 & 7 & 22 & 11 \\
\hline $6-7.9$ & 14 & 3 & 9 & 27 & 23 \\
\hline 8 or more & 10 & 7 & 8 & 14 & 24 \\
\hline Median \% & 4.3 & 3.8 & 3.7 & 5.7 & 5.7 \\
\hline Mean \% & 5.3 & 5.1 & 4.6 & 6.4 & 6.4 \\
\hline
\end{tabular}


However, they comprise only 32 percent of all schools and the overall median falls below the standard.

\section{STAFF}

Formula B of the Standards determines the adequate number of professional librarians needed by taking into account the number of students, book collection size, and annual book acquisitions. ${ }^{7}$ Such a procedure would seem to be a better indicator of staffing requirements than the percentage distribution in table 7 , and a more precise understanding of college library professional staffing in terms of Formula B is to be found in tables 8 and 9 . However, table 7 documents the relatively small size of professional staff, especially staffs in private undergraduate institutions, and complements the foregoing discussions of book stock and periodical subscriptions.

The Formula B procedures for calculating individual library professional staff needs are as follows:

one: For each 500 (or fraction) FTE students up to 10,000 one: For each 1,000 (or fraction) FTE students over 10,000

one: For each 100,000 volumes (or fraction) in the collection

one: For each 5,000 volumes (or fraction) added per year.

Table 8 shows us the number of staff needed for the large majority of libraries to meet the terms of Formula B.

The information about professional staff needs in table 8 is quite provocative- onethird of the libraries need four or more additional staff, and 81 percent fall below the standard. However, Formula B also has a grading system for professional staffing as follows ${ }^{8}$ :

\section{When supported by sufficient other} staff members

libraries that provide 100 percent of requirements are at level $\mathrm{A}$;

libraries that provide $75-99$ percent . . . are at level B;

libraries that provide $55-74$ percent ... are at level C;

libraries that provide $40-54$ percent ... are at level D.

TABLE 7

Number of Professional Staff

\begin{tabular}{|c|c|c|c|c|c|}
\hline $\begin{array}{l}\text { No. of } \\
\text { Prof. Staff }\end{array}$ & $\begin{array}{c}\text { Total } \\
(1,134)\end{array}$ & $\begin{array}{c}\text { Private } \\
\text { Grad. } \\
(261)\end{array}$ & $\begin{array}{c}\text { Private } \\
\text { Undgrad. } \\
(511)\end{array}$ & $\begin{array}{l}\text { Public } \\
\text { Grad. } \\
(287)\end{array}$ & $\begin{array}{c}\text { Public } \\
\text { Undgrad. } \\
\text { (75) }\end{array}$ \\
\hline $0-2$ & $19 \%$ & $11 \%$ & $34 \%$ & $2 \%$ & $11 \%$ \\
\hline $3-5$ & 37 & 41 & 49 & 11 & 40 \\
\hline $6-8$ & 18 & 25 & 13 & 19 & 32 \\
\hline $9-14$ & 14 & 16 & 5 & 29 & 13 \\
\hline 15 or more & 11 & 6 & 0 & 38 & 4 \\
\hline Median No. & 5.0 & 5.5 & 3.5 & 12.1 & 5.7 \\
\hline Mean No. & 7.2 & 6.6 & 3.9 & 14.1 & 6.5 \\
\hline
\end{tabular}

TABLE 8

Distribution of Professional StafF

Size According to Formula B Requirements

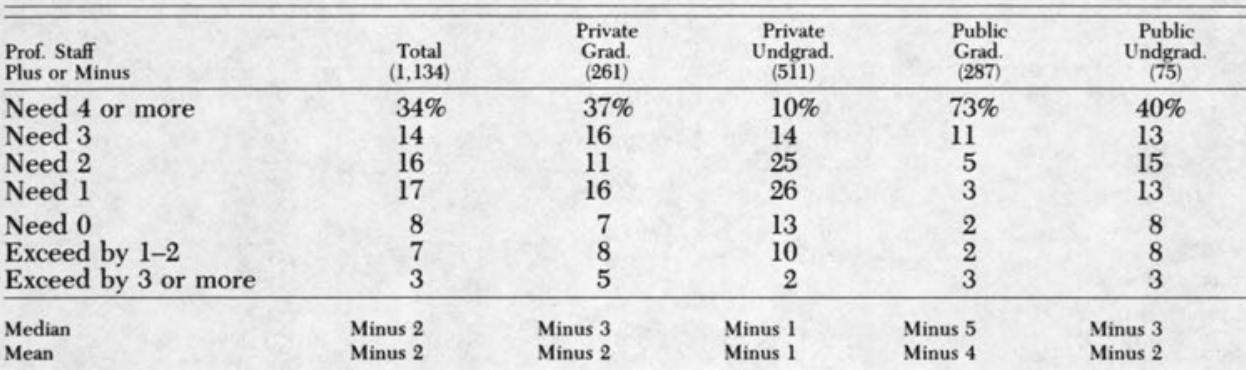


Table 9 reports the grade levels of libraries in these terms.

Fifty-one percent of public graduate institutions meet the B or better level, the best score by type of institution.

Table 10 shows the percentage distribution of support staff. The data in table 10 do not include any weighted factor for student assistance. Evidence for the qualification that professional staff be supported by sufficient other staff members is provided in table 11. The distribution of hours of student assistance appears in table 12.

The standards call for $25-35$ percent professionals as percent of staff. ${ }^{9}$ This would yield a ratio of about 1:3 (25 percent) to 1:1.9 (35 percent). On average, well over half of all libraries fall below the lower part of the range, 35 percent. The largest group of libraries by type, private undergraduate libraries, fares the worst with averages of fewer than one support staff member for each professional librarian.

The use of student assistants in libraries is generally considered to be a necessary, important, and efficient factor in library staffing. Table 12 displays the considerable variations in the employment of student assistants not only in the percentage distributions but also in the means and medians. As is the case with many other variables in this study, there is a contrast between public graduate and private undergraduate institutions.

Interpreting hours of student assistance as a staffing function is problematic; translating the hours into some kind of FTE staff equivalent invites a variety of procedures. For instance, if one staff position were to be defined as equal to 40 hours a week, 50

TABLE 9

GRADING OF LIBRARIES ACCORding to Formula B Requirements

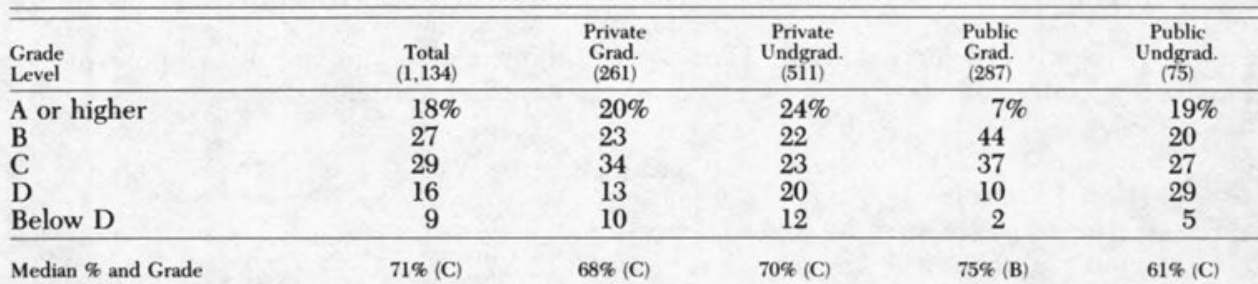

TABLE 10

Technical, Clerical, and Other Support StafF

\begin{tabular}{|c|c|c|c|c|c|}
\hline $\begin{array}{l}\text { No. of } \\
\text { Support Staff }\end{array}$ & $\begin{array}{c}\text { Total } \\
(1,134)\end{array}$ & $\begin{array}{c}\text { Private } \\
\text { Grad. } \\
\text { (261) }\end{array}$ & $\begin{array}{c}\text { Private } \\
\text { Undgrad. } \\
\text { (511) }\end{array}$ & $\begin{array}{l}\text { Public } \\
\text { Grad. } \\
(287)\end{array}$ & $\begin{array}{c}\text { Public } \\
\text { Undgrad. } \\
(75)\end{array}$ \\
\hline 0 & $6 \%$ & $5 \%$ & $10 \%$ & $0 \%$ & $1 \%$ \\
\hline $1-2$ & 27 & 21 & 45 & 3 & 17 \\
\hline $3-5$ & 22 & 26 & 29 & 8 & 24 \\
\hline $6-8$ & 13 & 15 & 10 & 13 & 24 \\
\hline $9-14$ & 14 & 19 & 5 & 23 & 25 \\
\hline 15 or more & 18 & 14 & 2 & 54 & 8 \\
\hline Median No. & 4.8 & 5.5 & 2.6 & 15.8 & 7.0 \\
\hline Mean No. & 8.9 & 7.8 & 3.5 & 19.9 & 8.2 \\
\hline
\end{tabular}

TABLE 11

Ratio of Professional to Support StafF

\begin{tabular}{|c|c|c|c|c|c|}
\hline & $\begin{array}{c}\text { Total } \\
(1,118)\end{array}$ & $\begin{array}{c}\text { Private } \\
\text { Grad. } \\
(254)\end{array}$ & $\begin{array}{c}\text { Private } \\
\text { Undgrad. } \\
(501)\end{array}$ & $\begin{array}{l}\text { Public } \\
\text { Grad. } \\
(286)\end{array}$ & $\begin{array}{c}\text { Public } \\
\text { Undgrad. } \\
(75)\end{array}$ \\
\hline Median & $1: 1.0$ & $1: 1.0$ & $1: 0.8$ & $1: 1.4$ & $1: 1.1$ \\
\hline Mean & $1: 1.1$ & $1: 1.9$ & $1: 0.9$ & $1: 1.4$ & $1: 1.3$ \\
\hline Maximum & $1: 9.0$ & $1: 9.0$ & $1: 5.2$ & $1: 4.6$ & $1: 5.6$ \\
\hline Minimum & $1: 0.0$ & $1: 0.0$ & $1: 0.0$ & $1: 0.0$ & $1: 0.0$ \\
\hline
\end{tabular}


TABLE 12

Hours of Student Assistance, Annual

\begin{tabular}{lccccc}
\hline \hline & $\begin{array}{c}\text { Total } \\
(1,122)\end{array}$ & $\begin{array}{c}\text { Private } \\
\text { Grad. } \\
(261)\end{array}$ & $\begin{array}{c}\text { Private } \\
\text { Undgrad. } \\
(503)\end{array}$ & $\begin{array}{c}\text { Public } \\
\text { Grad. } \\
(284)\end{array}$ & $\begin{array}{c}\text { Public } \\
\text { Undgrad. } \\
(74)\end{array}$ \\
\hline$<3,000$ & $26 \%$ & $21 \%$ & $34 \%$ & $15 \%$ & $32 \%$ \\
$<7,000$ & 28 & 28 & 36 & 14 & 22 \\
$<11,000$ & 15 & 18 & 17 & 8 & 23 \\
$<15,000$ & 18 & 24 & 11 & 26 & 12 \\
15,000 or more & 13 & 10 & 2 & 37 & 11 \\
\hline Median No. & 6,400 & 7,100 & 4,500 & 15,400 & 6,200 \\
Mean No. & 10,600 & 9,600 & 5,700 & 21,100 & 8,200
\end{tabular}

weeks a year, 2,000 hours of student assistance are required to "equal" a support staff position. Given the median and mean figures in table 12, libraries in aggregate gain from student assistance the equivalence of from two to five support positions. This is, of course, at best a crude estimate of the value of the flexibility in this kind of staffing, its cost, and its quality.

Other dimensions useful for approximating staff and collection development are presented in the following tables which relate professional staff size to the size of book collections and annual book acquisitions. Previous tables have shown that college libraries have rather modest collections and professional staff. The median book stock of these libraries is just above 110,000 volumes, annual additions are fewer than 5,000 volumes, and the median professional staff is $\mathbf{5 . 0}$ (one-third of private undergraduate institutions having two or fewer staff). Tables 13 and 14 provide an additional perspective: about 75 percent of libraries have one professional to "service" as many as 30,000 volumes and over 40 percent of the libraries have one staff member for the selection, processing, and dissemination of as many as $1,000-2,000$ volumes per year.

\section{Correlations: StafF, EnRollment, Collections}

During the examination of the tables on staffing, enrollment, the size of the book collection, and the number of book volumes added, several interesting relationships among these variables came to mind. Among them, hypotheses evolved that correlations existed between the size of staff and other variables - correlations that were high. Systematic analysis produced confirming results, producing moderate to moderately high positive correlations as shown in table 15.

Namely, the larger the staff, professional or professional plus support staff, the larger the number of volumes in the collection and the larger the number of students. However, recall that libraries with larger enrollments have fewer volumes per capita student (table 2). Nearly as strong a relationship is reflected in the correlation be-

TABLE 13

BOOKSTOCK VOLUMES PER Professional Librarian

\begin{tabular}{lc}
\hline $\begin{array}{l}\text { Ratio of Prof. Lbns. } \\
\text { to Book Collection }\end{array}$ & $\begin{array}{c}\text { Percent of Libraries } \\
(1,134)\end{array}$ \\
\hline $1:<10,000$ vols. & $4 \%$ \\
$1: 10,000-19,999$ & 39 \\
$1: 20,000-29,999$ & 31 \\
$1: 30,000-39,999$ & 16 \\
$1: 40,000$ or more & 10 \\
\hline
\end{tabular}

TABLE 14

Books AdDEd PER Professional Librarian

\begin{tabular}{lc}
\hline $\begin{array}{l}\text { Ratio of Prof. Lbns. } \\
\text { to Books Added }\end{array}$ & $\begin{array}{c}\text { Percent of Libraries } \\
(1,134)\end{array}$ \\
\hline $1:<1,000$ & $53 \%$ \\
$1: 1,000-1,999$ & 39 \\
$1: 2,000$ or more & 8 \\
\hline
\end{tabular}

TABLE 15

CORRELATIONS

\begin{tabular}{|c|c|c|c|}
\hline & $\begin{array}{c}\text { Book } \\
\text { Vols. Held }\end{array}$ & $\begin{array}{c}\text { FTE } \\
\text { Students }\end{array}$ & $\begin{array}{l}\text { Books } \\
\text { Added }\end{array}$ \\
\hline $\begin{array}{l}\text { Professional } \\
\text { Staff } \\
\text { Probability } \\
\text { No. of Libs. }\end{array}$ & $\begin{array}{l}r=.81 \\
.0001 \\
1134\end{array}$ & $\begin{array}{l}r=.84 \\
.0001 \\
1134\end{array}$ & $\begin{array}{l}r=.71 \\
.0001 \\
1134\end{array}$ \\
\hline $\begin{array}{l}\text { Professional } b \\
\text { Support Staff } \\
\text { Probability } \\
\text { No. of Libs. }\end{array}$ & $\begin{array}{c}r=.85 \\
.0001 \\
1134\end{array}$ & $\begin{array}{l}r=.87 \\
.0001 \\
1134\end{array}$ & $\begin{array}{l}r=.75 \\
.0001 \\
1134\end{array}$ \\
\hline
\end{tabular}


tween staff size and collection development as measured by "books added." On the other hand, these relationships exist within quite strict parameters: staff size, collection size, enrollment, and book acquisitions are in the aggregate quite small, especially in terms of the Standards.

\section{BUDGET}

The standards call for a minimum of 6 percent of the institution's budget, exclusive of capital and physical maintenance expenditures, to be allocated to the library. Following are tables of library operating expenditures, including a table showing how well libraries are faring with the 6 percent "rule" (table 16).

Summarizing for all libraries, 84 percent are allocated less than 6 percent of their institutional budgets, and more than one-third receive less than 4 percent. Institutions with 3,000-5,000 student enrollments fare the best, but even these and the largest institutions fail by four or more to one to meet the 6 percent standard. This critical budgetary standard is simply not met by the great majority of libraries.
As enrollment size and size of faculty should tend to correlate, the results in table 17 are similar to those in the preceding table with distribution by FTE students. Larger faculties do not accompany larger percentage allocations of budgets to the library.

While specific dollar amounts for library operations are not specified in the Standards, the following tables provide some additional sensitivity about library budgets by showing total operating dollar expenditures, expenditures for salaries and wages, and for materials.

As shown in table 18, public graduate institutions have far larger budgets than the other types; more than two-thirds of these 287 schools have more than one-half-million dollars for library operating expenditures. The contrast among the median budgets highlights the differences among the institutional types.

Table 19 reports $\$ 100,000$ as an approximation for salaries and wages. Assuming the medians of five each professional and support staff (tables 7 and 9) and discounting any allocation for student wages, the

TABLE 16

Library Expenditure as a Percent of InSTITUTIONAL EXPENDITURE, BY FTE STUDENTS

\begin{tabular}{|c|c|c|c|c|c|}
\hline $\begin{array}{l}\text { Lib. \% } \\
\text { of Budget }\end{array}$ & $\begin{array}{c}\text { Total } \\
(1,132)\end{array}$ & $\begin{array}{c}<1,000 \\
(345)\end{array}$ & $\begin{array}{c}\text { FTE Students } \\
<2,000 \\
(306)\end{array}$ & $\begin{array}{c}<5,000 \\
(263)\end{array}$ & $\begin{array}{c}5,000 \text { or More } \\
(218)\end{array}$ \\
\hline$<3$ & $12 \%$ & $15 \%$ & $11 \%$ & $11 \%$ & $11 \%$ \\
\hline$<4$ & 26 & 27 & 30 & 25 & 20 \\
\hline$<5$ & 29 & 26 & 29 & 28 & 36 \\
\hline$<6$ & 17 & 18 & 16 & 16 & 19 \\
\hline Cumulative \% & & & & & \\
\hline Below 6\% & (84) & (86) & (86) & $(80)$ & (86) \\
\hline $6-6.9$ & 8 & 5 & 7 & 10 & 10 \\
\hline 7 or more & 8 & 10 & 7 & 10 & 4 \\
\hline
\end{tabular}

Median, all institutions, $4.3 \%$

Mean, all institutions, $4.8 \%$

TABLE 17

Library Expenditure as a Percent of INSTITUTIONAL EXPENDITURE, BY SIZE OF FACULTY

\begin{tabular}{|c|c|c|c|c|c|}
\hline $\begin{array}{l}\text { Lib. \% } \\
\text { of Budget }\end{array}$ & $\begin{array}{c}\text { Total } \\
(1,128)\end{array}$ & $\begin{array}{l}<50 \\
(319)\end{array}$ & $\begin{array}{c}\text { Number of Faculty } \\
<100 \\
(360)\end{array}$ & $\begin{array}{l}<200 \\
(246)\end{array}$ & $\begin{array}{c}200 \text { or More } \\
(203)\end{array}$ \\
\hline$<3$ & $12 \%$ & $15 \%$ & $14 \%$ & $8 \%$ & $9 \%$ \\
\hline$<4$ & 26 & 24 & 31 & 27 & 20 \\
\hline$<5$ & 29 & 27 & 28 & 28 & 37 \\
\hline$<6$ & 17 & 15 & 16 & 19 & 19 \\
\hline$<7$ & 8 & 6 & 6 & 11 & 10 \\
\hline 7 or more & 8 & 12 & 6 & 7 & 4 \\
\hline
\end{tabular}


TABLE 18

TOTAL OPERATING EXPENDITURES FOR LibRaRIES

\begin{tabular}{|c|c|c|c|c|c|}
\hline $\begin{array}{l}\text { Total Lib. } \\
\text { Budget (\$) }\end{array}$ & $\begin{array}{c}\text { Total } \\
(1,134)\end{array}$ & $\begin{array}{c}\text { Private } \\
\text { Grad. } \\
(261)\end{array}$ & $\begin{array}{c}\text { Private } \\
\text { Undgrad. } \\
\text { (511) }\end{array}$ & $\begin{array}{l}\text { Public } \\
\text { Grad. } \\
(287)\end{array}$ & $\begin{array}{c}\text { Public } \\
\text { Undgrad. } \\
(75)\end{array}$ \\
\hline$<\$ 75,000$ & $12 \%$ & $6 \%$ & $23 \%$ & $0 \%$ & $1 \%$ \\
\hline$<100,000$ & 10 & 9 & 17 & 1 & 5 \\
\hline$<200,000$ & 28 & 26 & 41 & 5 & 25 \\
\hline$<500,000$ & 28 & 44 & 16 & 27 & 53 \\
\hline$<1$ million & 14 & 12 & 2 & 37 & 12 \\
\hline 1 million or more & 8 & 3 & 0 & 30 & 3 \\
\hline Median &, 000 & $\$ 232,000$ & $\$ 113,000$ & $\$ 717,000$ & 264,000 \\
\hline Mean & 1,000 & $\$ 297,000$ & $\$ 146,000$ & $\$ 826,000$ & 326,000 \\
\hline
\end{tabular}

TABLE 19

Salaries and Wages Budgets

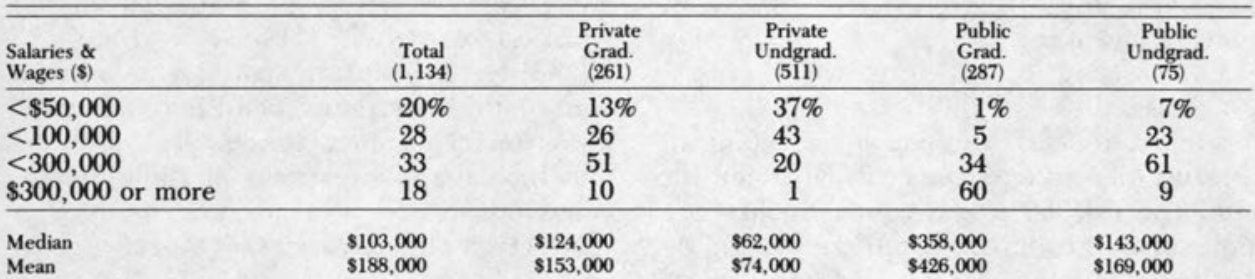

salaries of college library staffs are presumably quite low. Five professionals with a median salary of $\$ 11,000$ and five support staff with a median of $\$ 9,000-1977$ dollars-would require $\$ 100,000$. The quality of service so long sought for and strongly emphasized in the standards may depend in no small part on financial compensation adequate to attract staff appropriate in quality to the level of services in libraries' objectives.

The materials budget figures in table 20 are hardly remarkable considering the median purchase of fewer than 5,000 book volumes per year. The average price (1977) per volume of hardcover books, excluding those costing $\$ 81.00$ or more, was $\$ 17.32 .{ }^{10}$ The overall median materials budget would permit purchase of about 4,100 volumes assuming a 10 percent discount from the average price cited. (This does not allow for purchase of periodicals, audiovisuals, etc.) Libraries, of course, must acquire titles costing $\$ 81.00$ or more; such titles added to the total publications, raise 1977's mean cost to $\$ 19.22$, reducing the number of volumes even further for all libraries, and clearly having considerable effect on the $\mathbf{5 0}$ percent of all libraries having less than $\$ 64,000$ for materials and the 50 percent of private undergraduate schools with less than $\$ 36,000$ for all materials.

TABLE 20

Materials Budgets

\begin{tabular}{lccccc}
\hline \hline & $\begin{array}{c}\text { Total } \\
(1,134)\end{array}$ & $\begin{array}{c}\text { Private } \\
\text { Grad. } \\
(261)\end{array}$ & $\begin{array}{c}\text { Private } \\
\text { Undgrad. } \\
(511)\end{array}$ & $\begin{array}{c}\text { Public } \\
\text { Grad. } \\
(287)\end{array}$ & $\begin{array}{c}\text { Public } \\
\text { Undgrad. } \\
(75)\end{array}$ \\
\hline Materials $(\$)$ & $16 \%$ & $10 \%$ & $30 \%$ & $0 \%$ & $7 \%$ \\
\hline$<25,000$ & 24 & 23 & 36 & 3 & 16 \\
$<50,000$ & 23 & 31 & 25 & 9 & 40 \\
$<100,000$ & 26 & 32 & 9 & 47 & 36 \\
$<300,000$ & 11 & 5 & 0 & 40 & 1 \\
$\$ 300,000$ or more & $\$ 64,000$ & $\$ 70,000$ & $\$ 36,000$ & $\$ 237,000$ & $\$ 89,000$ \\
\hline Median & $\$ 124,000$ & $\$ 100,000$ & $\$ 49,000$ & $\$ 285,000$ & $\$ 109,000$
\end{tabular}


Depending upon local factors, between 35 and 45 percent of the library's budget is normally allocated to the purchase of materials and between 50 and 60 percent is expended for personnel. ${ }^{11}$

The fact that the proportions allocated for personnel and materials from the total operating budget of libraries collectively are up to standard (table 21) may be of small comfort when we recall that 80 percent or more of all types of libraries receive less than 6 percent of the institutional budget and that median total operating budgets are about $\$ 200,000$ with $\$ 113,000$ for private undergraduate institutions. From a policy point of view, however, the proportions cited in the Standards are satisfactorily met with exceptional uniformity.

\section{SERVICE}

Among the following tables are four indicators of service. Data available for this study provide far less insight into the "output" than the "input" of libraries. Of the four indicators presented below, only one reflects directly on the standards for service: that "the public's need for access to libraries may range upward to 100 hours per week ..." "12 The availability of library services elsewhere and conjointly provided by library cooperation is in no way measurable with the NCES data base; each library stands alone in this respect as in others. Nonetheless, as table 22 shows, the 100 hours per week "standard" seems to be approximately met, with considerable range as indicated by the minimum and maximum hours.

The ratio of professional library staff to students is more favorable in private than in public-controlled schools (table 23). Nonetheless, if library staffs are to provide "adequate" services, including the wider adoption of on-line bibliographic searches and bibliographic instruction, these staffing ratios suggest the need for more professionals. Also, the data base reinforces the

TABLE 21

Aggregate Mean Percent of Total Budget for Materials and PERSONNEL

\begin{tabular}{|c|c|c|c|c|c|}
\hline & $\begin{array}{c}\text { Total } \\
(1,134)\end{array}$ & $\begin{array}{c}\text { Private } \\
\text { Grad. } \\
\text { (261) }\end{array}$ & $\begin{array}{c}\text { Private } \\
\text { Undgrad. } \\
\text { (511) }\end{array}$ & $\begin{array}{l}\text { Public } \\
\text { Grad. } \\
(287)\end{array}$ & $\begin{array}{c}\text { Public } \\
\text { Undgrad. } \\
(75)\end{array}$ \\
\hline Materials & $34 \%$ & $34 \%$ & $34 \%$ & $35 \%$ & $33 \%$ \\
\hline Personnel & $51 \%$ & $51 \%$ & $51 \%$ & $52 \%$ & $52 \%$ \\
\hline
\end{tabular}

TABLE 22

Hours OPEN PER WeEK

\begin{tabular}{|c|c|c|c|c|c|}
\hline & $\begin{array}{c}\text { Total } \\
(1,135)\end{array}$ & $\begin{array}{c}\text { Private } \\
\text { Grad. } \\
(261)\end{array}$ & $\begin{array}{c}\text { Private } \\
\text { Undgrad. } \\
(510)\end{array}$ & $\begin{array}{c}\text { Public } \\
\text { Grad. } \\
(287)\end{array}$ & $\begin{array}{c}\text { Public } \\
\text { Undgrad. } \\
(75)\end{array}$ \\
\hline Median & 82 & 85 & 78 & 85 & 77 \\
\hline Mean & 82 & 86 & 79 & 85 & 76 \\
\hline Minimum & 9 & 49 & 9 & 49 & 52 \\
\hline Maximum & 168 & 168 & 168 & 168 & 93 \\
\hline
\end{tabular}

TABLE 23

Professional Librarians Per FTE Student

\begin{tabular}{|c|c|c|c|c|c|}
\hline $\begin{array}{l}\text { Ratio of Prof } \\
\text { Lbns. to Students }\end{array}$ & $\begin{array}{c}\text { Total } \\
(1,116)\end{array}$ & $\begin{array}{c}\text { Private } \\
\text { Grad. } \\
(254)\end{array}$ & $\begin{array}{c}\text { Private } \\
\text { Undgrad. } \\
(501)\end{array}$ & $\begin{array}{l}\text { Public } \\
\text { Grad. } \\
(286)\end{array}$ & $\begin{array}{c}\text { Public } \\
\text { Undgrad. } \\
(75)\end{array}$ \\
\hline $1:<200$ & $18 \%$ & $17 \%$ & $29 \%$ & $1 \%$ & $9 \%$ \\
\hline $1: 200-299$ & 23 & 23 & 33 & 7 & 21 \\
\hline $1: 300-399$ & 19 & 19 & 20 & 15 & 16 \\
\hline $1: 400-699$ & 29 & 27 & 14 & 54 & 40 \\
\hline 1:700 or more & 11 & 13 & 4 & 23 & 13 \\
\hline Median Ratio & $1: 350$ & $1: 340$ & $1: 260$ & $1: 530$ & $1: 430$ \\
\hline Mean Ratio & $1: 410$ & $1: 440$ & $1: 310$ & $1: 570$ & $1: 460$ \\
\hline
\end{tabular}


findings in table 9 , that professional staff size is quite rarely up to Standard B.

The range of loans per FTE student (table 24) is very large-from less than one per student in nine libraries to 302 in one library. The tenth and ninetieth percentiles provide a more compact basis for comparison but nonetheless suggest great disparities in this measure of service (use).

The use of reference services as reported by about 90 percent of the college libraries is potential evidence for the need to develop bibliographic instruction and related programs. Only 5 percent of libraries fractionally report more than one reference (or directional) transaction per student per week (table 25). Private undergraduate libraries are more active in this respect than are the other types of libraries; their weekly .25 median may support the deduction that students at such schools, on average, ask more questions a month regarding library resources and services.

\section{SUMMARY AND CONCLUSION}

The analysis of the 1977 HEGIS data yielded many conclusions about college libraries that may be briefly summarized as follows:

A.1. Libraries serving institutions with no or very few post-baccalaureate programs fail on average to meet the Standards for the basic book collection; further, nearly half have fewer than 500 periodical title subscriptions.

A.2. Three-fourths of privately controlled schools, including those with graduate programs, added less than 5 percent to their book stock in 1977. The majority of all institutions acquired fewer than 5,000 volumes each that year.

A.3. From 77-91 percent of those libraries serving enrollments of fewer than 2,000 students (a majority of the schools) hold fewer than 150 volumes per student.

B.1. The number of staff members in college libraries is characteristically modest; the 511 private undergraduate schools have two or fewer professional librarians. Application of the Standards' formula for professional staff indicates that all types of libraries fall far short of the standard. Private undergraduate schools rate better than the other three classes in terms of the raw numbers needed; however, when classed by the formula's grading system they rank quite similarly with others as about $39-51$ percent of all libraries rank B or higher.

B.2. The ratio of professional to support staff is on average about $1: 1$, a fact not likely to appear cost- or service-effective.

C. The Standards' expectation that institutions allocate 6 percent of their operating budgets to the library is met by only 16 percent of these schools. The median (4.3 percent) allocation is 30 percent below the

TABLE 24

AnNual Loans PER FTE Student

\begin{tabular}{lccccc}
\hline \hline & $\begin{array}{c}\text { Total } \\
(1,132)\end{array}$ & $\begin{array}{c}\text { Private } \\
\text { Grad. } \\
(260)\end{array}$ & $\begin{array}{c}\text { Private } \\
\text { Undgrad. } \\
(510)\end{array}$ & $\begin{array}{c}\text { Public } \\
\text { Grad. } \\
(287)\end{array}$ & $\begin{array}{c}\text { Public } \\
\text { Undgrad. } \\
(75)\end{array}$ \\
\hline Median & 19 & 20 & 23 & 15 & 16 \\
Mean & 24 & 25 & 27 & 18 & 20 \\
10th percentile & 8 & 6 & 9 & 7 & 6 \\
90th percentile & 42 & 46 & 47 & 31 & 36 \\
\hline
\end{tabular}

TABLE 25

Directional and Reference Transactions PER FTE STUDENT PER WEEK

\begin{tabular}{lccccc}
\hline \hline & $\begin{array}{c}\text { Total } \\
(997)\end{array}$ & $\begin{array}{c}\text { Private } \\
\text { Grad. } \\
(233)\end{array}$ & $\begin{array}{c}\text { Private } \\
\text { Undgrad. } \\
(\mathbf{4 4 3 )}\end{array}$ & $\begin{array}{c}\text { Public } \\
\text { Grad. } \\
(254)\end{array}$ & $\begin{array}{c}\text { Public } \\
\text { Undgrad. } \\
(67)\end{array}$ \\
\hline Median & .17 & .18 & .25 & .10 & .14 \\
Mean & .33 & .26 & .45 & .18 & .24 \\
10th Percentile & .05 & .05 & .07 & .04 & .04 \\
90th Percentile & .66 & .57 & .91 & .36 & .47 \\
95th Percentile & 1.08 & .74 & 1.47 & .47 & 1.14 \\
\hline
\end{tabular}


standard 6 percent. The expenditures for materials and personnel reflect clearly the very modest sums appropriated for library expenditures in all four classes of institutions.

D. Access to and use of libraries, as measured here, is equally moderate.

In sum, for most libraries it seems fair to say that they are underdeveloped, understaffed, and underused.

Assuming that the Standards are reasonable, far greater support for all library functions is required for the great majority of libraries. While the particulars of each formula for collection size and staff as well as other parts of the Standards may well be open to revision, the data presented here on these basic indicators of library behavior suggest that any serious reduction in the quantitative aspects of the Standards may mean concession to inferior quality. After all, a collection of fewer than 100,000 volumes and a professional staff member to serve each $350-400$ students (plus faculty and other patrons) are presumably not adequate much less "ideal" goals-yet these are the median measures of these characteristics for most libraries.

This analysis is intended to clarify the status of libraries in as many respects as possible, given the available data, in order to facilitate understanding of the Standards' implications. In the future perhaps the clarification will be fuller, for many factors cannot now be measured because there are no relevant data systematically collected. As data collection and analysis increase, the perspective of empirical conditions in contrast with those of the Standards may not only itself improve, but also the conditions of the libraries may improve. This occurs often when surveillance and analysis of an organization imply more intense interest in and heightened valuation of the organization as well as sensitivity to its needs.

\section{REFERENCES}

1. "Standards for College Libraries," College $b$ Research Libraries 36:277-79, 290-301 (Oct. 1975).

2. Carnegie Commission on Higher Education, A Classification of Institutions of Higher Education: A Technical Report (Berkeley, California, 1973).

3. "Standards for College Libraries," p.277.

4. Ibid., p. 290.

5. Ibid., p. 290 .
6. Chandler P. Grannis, "Updated Book Output Statistics, 1978," Publishers Weekly 216, no. 10:44 (Sept. 3, 1979).

7. "Standards for College Libraries," p.291.

8. Ibid., p. 291

9. Ibid., p. 292

10. Grannis, "Updated Book Output Statistics, 1978 ," p.47.

11. "Standards for College Libraries," p. 299.

12. Ibid., p. 293 